\title{
Клінічна ефективність інгібіторів тирозинкінази у пацієнтів з НДРЛ та рідкісними EGFR-мутаціями: результати клінічних досліджень та власний досвід лікування пацієнта з НДРЛ на фоні COVID-19
}

\author{
DOI: 10.32471/clinicaloncology.2663-466X.41-1.27691
}

\begin{abstract}
Наприкінці минулого року відбулася Науково-практична фахова школа у форматі прямої оnline-трансляції «Недрібноклітинний рак легені - український досвід впровадження сучасних стандартів діагностики та лікування", у ході якої розглядалися візуальні та інвазивні методи діагностики недрібноклітинного раку легені (НдРл), а також персоналізована терапія НДРЛ, новоутворень легені та середостіння. Під час заходу відбулися 3 відео-майстер-класи 3 проведення інвазивних методів діагностики пухлин легені. Серед доповідей, представлених в рамках школи, особливу увагу привернула лекція Олександра Анатолійовича Суховерши, доктора медичних наук, онкоторакального хірурга, доцента кафедри онкології та медичної радіології ДЗ «Дніпропетровська медична академія МОз України», м. Дніпро, яка була присвячена питанням лікування пацієнтів з НДРЛ та рідкісними мутаціями рецептора епідермального фактора росту, зокрема інгібіторами тирозинкінази. Олександр Анатолійович представив увазі учасників заходу клінічний випадок лікування пацієнтки з НДРЛ та рідкісними мутаціями рецептора епідермального фактора pocty (epidermal growth factor receptor - EGFR) із застосуванням інгібітора тирозинкінази (ITK) 3-го покоління - осимертинібу. Варто відмітити, що пацієнтка успішно вилікувалася від COVID-19 і протягом терапії цього інфекційного захворювання не було потреби припиняти застосування осимертинібу.
\end{abstract}

Успіхи в лікуванні хворих на недрібноклітинний рак легені (НДРЛ) з мутаціями рецептора епідермального фактора росту (epidermal growth factor receptor - EGFR) є справжнім проривом у терапії онкопатології. Застосування інгібіторів тирозинкінази (ITK) у таких пацієнтів суттєво поліпшило результати лікування та якість їх життя.

Основою вважається відкриття ролі активуючих мутацій EGFR. «Класичними» мутаціями EGFR при НДРЛ $€$ точкова мутація L858R у 21-му екзоні (38\%) та делеції у 19-му екзоні (46\%). Окрім того, за допомогою секвенування можуть бути виявлені і більш рідкісні мутації, які становлять $10-15 \%$ серед усіх мутацій EGFR, а саме:

- G719X у 18-му екзоні;

- S768I в 20-му екзоні;

- інсерції у 20-му екзоні;

- L861Q у 21-му екзоні.

Лікування пацієнтів з рідкісними мутаціями є суттєвою проблемою.

Аналіз результатів ряду клінічних досліджень та точки зору окремих авторів демонструє практично повну відсутність ефекту від застосування ITK 1-го покоління для лікування пацієнтів з рідкісними мутаціями EGFR.

Показники виживаності без прогресії (ВБП) захворювання коливалися в межах 0,9-3,0 міс, що гірше за результати лікування за допомогою хіміотерапії. Саме тому хіміотерапія розглядалася як метод вибору під час лікування даної групи пацієнтів.

Упродовж останніх років відмічено окремі позитивні наслідки лікування пацієнтів з рідкісними мутаціями EGFR ITK 2-го покоління (афатініб), які опубліковані Yang в 2015-2016 pр., однак ці результати було отримано для хворих азіатського походження. А невелика кількість спостережень цих авторів не дозволяє робити висновки щодо достовірності цих результатів. Це відмічено для мутацій, що локалізовані як у 18-му, так і в 20-му екзоні.
Результати терапії пацієнтів 3 точковими мутаціями у 20-му екзоні при застосуванні ITK 1-2-го покоління також є незадовільними. Схожа картина спостерігається і для НДРЛ з точковими мутаціями L861Q у 21-му екзоні. Показники ВБП не перевищують 8,2 міс. Також відсутній ефект від ITK 1-го та 2-го покоління за наявності інсерцій у 20-му екзоні. У такому разі показники ВБП взагалі не перевищують 3 міс.

Упродовж останніх років започатковано дослідження ефективності ITK 3-го покоління для лікування хворих на НДРЛ з рідкісними мутаціями EGFR.

Найвищу ефективність та перспективність застосування демонструє осимертиніб.

Мабуть, найбільшим за обсягом в останні роки є дослідження $\mathrm{YanRu}$ Qin та співавторів із Шанхайского онкологічного центру. У роботі проаналізовано молекулярну структуру у близько 25 тис. пацієнтів з НДРЛ та мутацією EGFR. Загалом було виявлено 547 випадків мутацій з інсерцією в 20 екзоні. Далі проведено секвенування відібраних 547 випадків мутацій з щонайменше 1 епізодом EGFR e20ins (2,24\%). Більшість інсерцій полягали у «вставці» 1-3 амінокислот. Найчастіше спостерігалися інсерції p.A767_V769dup (25,1\%, n=145), p.S768 D770dup $(17,6 \%, n=96)$. Спектр виявлених інсерцій та інших генетичних альтерацій налічував більше 10 варіантів.

Серед 547 хворих було 52,7\% жінок (288), морфологічно переважали аденокарциноми $(77,9 \%)$. В основному були представлені місцево-поширені та метастатичні форми раку.

Лікування із застосуванням ITK EGFR отримували 65 пацієнтів, зокрема:

- ITK 1-го покоління - 51 хворий;

- афатініб - 10 пацієнтів; 
- позіотиніб (poziotinib NOV120101, НM781-36B) 12 хворих;

- осимертиніб - 22 пацієти.

Слід зауважити, що позіотиніб та осимертиніб належать до ITK 3-го покоління.

Результати лікування - ВБП - оцінювалися залежно від варіанту мутації та препарату, що застосовувався. Найкращі результати щодо ВБП було отримано в групі пацієнтів, що отримували осимертиніб.

Серед 65 хворих, які лікувались ITK, 15 пацієнтів отримували щонайменше 2 ITK послідовно.

Саме осимертиніб у 2-й лінії терапії продемонстрував найвищу ефективність.

У якості наочного прикладу автори дослідження представили клінічний випадок.

Хворий з НДРЛ IV ст. 3 наявністю інсерції в 20-му екзоні EGFR (p.A763_Y764insFQEA) отримував послідовну терапію з використанням різних ITK. Хворому проводився періодичний геномний моніторинг зразків пухлини, плазми крові та спинномозкової рідини. У якості I лінії терапії пацієнт отримував гефітиніб протягом 9 міс, допоки не розвилася резистентність до цього препарату, обумовлена появою мутації Т790М. У якості ІІ лінії терапії було застосовано осимертиніб, який хворий приймав 7 міс, поки не було виявлено метастази в головному мозку. При цьому було зафіксовано різке підвищення рівня інсерції EGFR (p.A763_Y764insFQEA - 53\%) та одночасне збільшення копій онкогенів $M E T$ та $M Y C$. Ці поєднані зміни могли бути причиною поширення метастазів у головний мозок. Тому пацієнту додатково до осимертинібу був призначений AZD3759 - ITK EGFR, який спеціально розроблявся для застосування у разі поширення метастазів у головний мозок при мутаціях $M E T$. Завдяки цій комбінації хворий був стабільним протягом 9 міс.

Автори даного дослідження вважають, що це може бути прикладом поетапного етіопатогенетичного лікування хворого з інсерцією у 20-му екзоні.

Нещодавнє дослідження В. van Veggel та співавт. з Hiдерландів також було присвячене вивченню ефективності осимертинібу у пацієнтів з НДРЛ IV стадії та інсерцією в 20-му екзоні.

У дослідження було включено 21 пацієнта, що отримували терапію осимертинібом ( 80 або 160 мг). Варто зазначити, що у 11 з цих пацієнтів було виявлено метастази в головному мозку.

17 пацієнтів отримували поетапну терапію, у якості I лінії для 13 з них було обрано хіміотерапію препаратами платини, 3 пацієнти отримували ITK EGFR (1 - гефітініб, 2 - афатініб) та 1 пацієнт - люмінеспіб (HSP-90-інгібітор). Середня тривалість лікування становила 4 міс. Секвенування пухлин показало наявність інсерцій в ділянці між Ala767 та Gly779. Найчастіше відмічали такий варіант інсерцій, як Ala767_Val769dup $(\mathrm{n}=4)$. Також у 8 випадках з 13 (62\%) виявили комутації ТР53. Автори відмічають, що в ході терапії було досягнуто певних результатів. Так, було зареєстровано 1 часткову відповідь, 17 випадків стабілізації перебігу захворювання та лише 3 випадки прогресування захворювання.

Медіана ВБП становила 3,6 міс (95\% довірчий інтервал (ДІ) 2,6-4,5) і не залежала від наявності комутацій. При цьому загальна виживаність (3В) становила 8,7 міс (95\% ДІ 1,1-16,4)

Частота об’єктивної відповіді (ЧОВ) була низькою і становила лише 5\%. Однак у 14 з 21 пацієнтів (67\%) спостерігалось зменшення розмірів пухлини. Базуючись на отриманих даних, автори дослідження прийшли до висновків, що на відміну від ITK 1-го та 2-го покоління осимертиніб має обмежену ефективність у лікуванні хворих з EGFR 3 інсерцією в 20-му екзоні. Відтак дослідження дієвості осимертинібу у цієї групи пацієнтів потребує подальших широкомасштабних клінічних досліджень.

В останні роки було започатковано проведення рандомізованих клінічних досліджень ефективності ІTК 3-го покоління при терапії пацієнтів з НДРЛ та рідкісними мутаціями EGFR.

Однією з перших таких робіт стало дослідження корейських вчених - KCSG-LU15-09, у якому взяли участь 36 пацієнтів (22 чоловіки та 14 жінок). Проведене секвенування зразків виявило основні «рідкісні» мутації EGFR:

- G719X у 18-му екзоні (53\%);

- L861Q в 21-му екзоні (25\%);

- S768I в 20-му екзоні (22\%).

У якості І лінії терапії осимертиніб (80 мг) отримували $22(61 \%)$ пацієнта, в якості II лінії терапії - 11 пацієнтів (31\%) та в якості III лінії терапії - 3 (8\%) пацієнти.

Редукція пухлини після застосування осимертинібу спостерігалася у 28 пацієнтів (78\%). При цьому середній показник редукції пухлини становив 44\%. Найкращі показники ЧОВ та медіани ВБП спостерігалися для мутацій L861Q (21-й екзон) S768I (20-й екзон). Відповідно до отриманих результатів ЧОВ становила 50\% (18 з 36 пацієнтів), а медіана ВБП $-8,2$ міс. Медіана тривалості відповіді на лікування становила 11,2 міс.

Профіль безпеки терапії був прийнятним. Так, спостерігалися лише побічні ефекти 1-2-го ступеня, а саме: висипання - у $31 \%$ пацієнтів, свербіж - у 25\%, зниження апетиту $-25 \%$, діарея $-22 \%$, задишка $-22 \%$.

У цілому корейські автори роблять висновок про високу ефективність та прийнятний профіль безпеки осимертинібу в лікуванні рідкісних мутацій EGFR.

Ще одне рандомізоване дослідження II фази ECOGACRIN 5162 присвячене вивченню ефективності осимертинібу (в дозі 160 мг) при лікуванні НДРЛ з мутаціями в 20-му екзоні. У дослідження включено 21 пацієнта, 3 них 15 жінок, у яких було вивчено субструктуру мутацій в 20-му екзоні. Відповідно до отриманих результатів у 1 пацієнта зареєстрована повна відповідь на лікування, у 4 пацієнтів - часткова відповідь, у 12 (60\%) пацієнтів стабілізація перебігу захворювання. ЧОВ становила $25 \%$, а медіана ВБП - 9,7 міс.

Токсичність терапії осимертинібом була невисокою. Так, відмічалися небажані явища 1-2 ступеня, а саме: діарея (76\%), слабкість (67\%), тромбоцитопенія (67\%), анемія (43\%), лейкопенія (43\%), анорексія (43\%). Серед небажаних явищ 3-го ступеня були зафіксовані слабкість (10\%), анемія $(10 \%)$, подовження інтервалу $Q-T c(10 \%)$, анорексія $(5 \%)$. Лише в 1 випадку зареєстровано небажане явище 4-го ступеня - дихальна недостатність.

\section{ВПЛИВ КОМУТАЦІЙ НА ЕФЕКТИВНІСТЬ ЛІКУВАННЯ ITK EGFR}

Цікавим також є питання впливу комутацій на ефективність лікування ITK EGFR. Практично в усіх дослідженнях, які аналізувалися раніше, були відмічені численні випадки таких поєднань. Експресія PD-L1 і мутації EGFR при НДРЛ не є взаємовиключними.

Застосування осимертинібу в якості І лінії терапії є клінічно ефективним у пацієнтів з поширеним НДРЛ EGFRm, незалежно від статусу PD-L1-експресії. Ці висновки містяться в спеціальному дослідженні канадської групи онкологів H. Brown та співавторів, результати якого опубліковані в 2018 р.

Wang та співавтори у дослідженні BENEFIT, також опублікованому у 2018 р., продемонстрували негативний вплив комутацій на ефективність лікування ITK 1-го покоління (гефітиніб) пацієнтів з НДРЛ та мутацією EGFR.

Lai G. C. та співавтори у 2019 р. повідомили результати лікування 26 пацієнтів з мутаціями EGFR та MET. Високий 

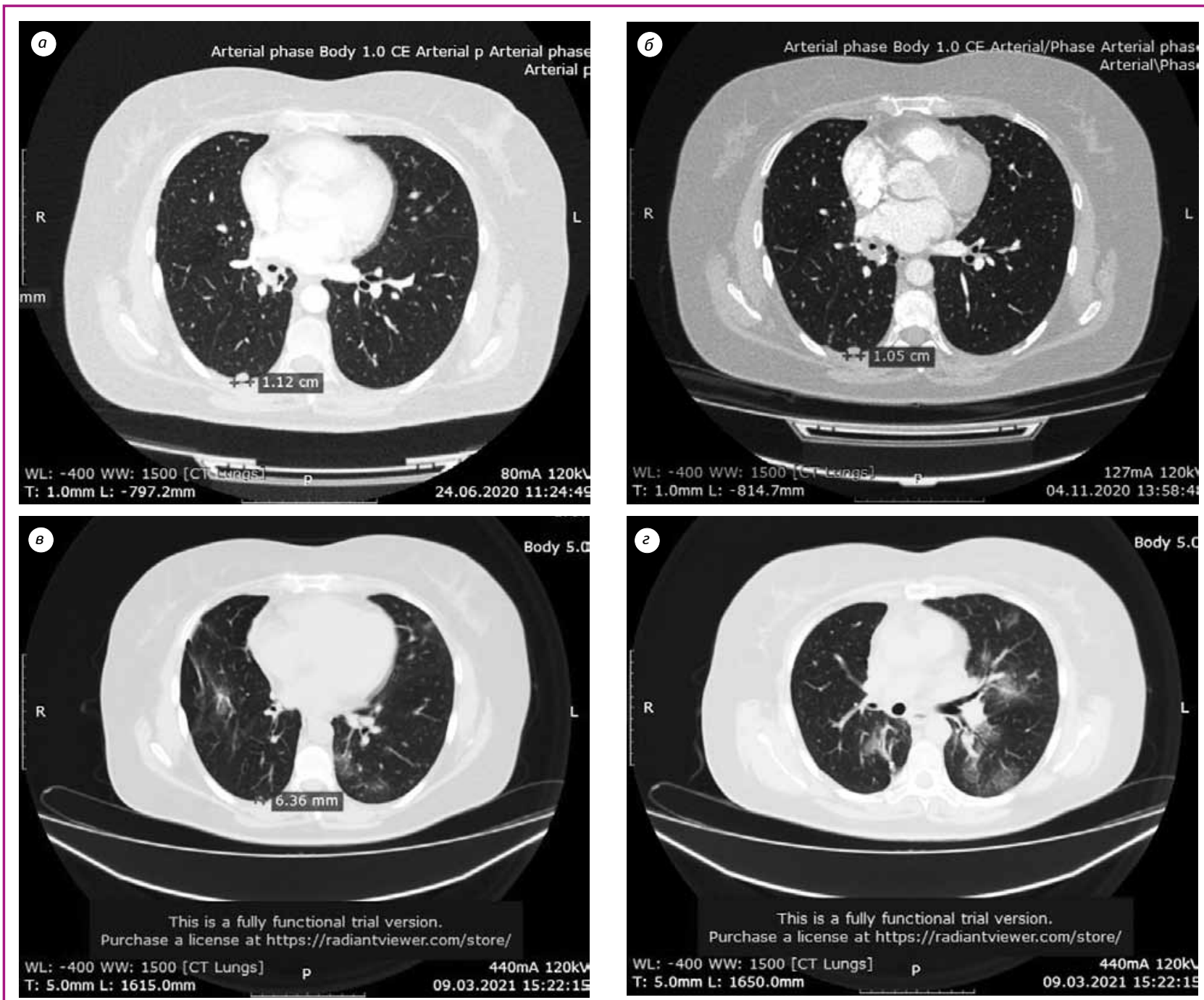

Рисунок. Динаміка за даними комп'ютерної томографії пацієнтки в ході таргетної терапії: a) 24 червня 2020 р. — прогресування хвороби в легені; б) 14 листопада 2020 р. - частковий регрес пухлини - 8\% за шкалою RECIST 1.1; в) 9 березня 2021 р. новоутворення у правій легені зменшилося з 12 до 6,5 мм; г) 9 березня 2021 р. - новоутворення 5 мм в лівій легені зникло

рівень копій онкогену МЕТ істотно не впливав на ефективність терапії ITK EGFR, за винятком пацієнтів з ампліфікаціями онкогену $M E T$. Автори рекомендують для цих випадків комбінацію ITK EGFR з інгібіторами MET.

Аналогічній проблемі було присвячене багатоцентрове відкрите рандомізоване дослідження фази Ib TATTON, розпочате в 2018 р. У ньому для лікування пацієнтів з НДРЛ EGFRm і ампліфікацією МЕT застосовується ITK 3-го покоління (осимертиніб) та інгібітор МЕТ (саволітиніб). Згідно з отриманими проміжними результатами ЧОВ була кращою у пацієнтів з ампліфікацією онкогену $M E T$, що раніше не застосовували ITK EGFR 3-го покоління, незалежно від статусу мутації Т790М.

Наявність комутацій також може розглядатися у якості прогностичного фактору, а не тільки як показання до зміни схеми терапії.

Як продемонстрували в своєму дослідженні у 2019 р. Roeper та співавтори, комутація TP53 у пацієнтів з EGFRm НДРЛ є незалежним негативним предиктивним фактором щодо ВБП і ЗВ.

Водночас, враховуючи високу частоту виявлення мутації ТP53, та її вплив на результати таргетної терапії ITK, розпочато перше рандомізоване дослідження комбінації ITK 3-го покоління (осимертиніб) з хіміотерапією (препарати платини+етопозид). Результати наразі ще невідомі.
Таким чином, проблема лікування НДРЛ з рідкісними мутаціями EGFR залишається складною, однак ми вже бачимо певні зрушення в напрямку її вирішення.

\section{КЛІНІЧНИЙ ВИПАДОК}

О.А. Суховерша представив до уваги учасників фахової школи клінічний випадок. Під спостереженням в ДЗ «Дніпропетровська медична академія MO3 України» знаходиться пацієнтка з рідкісною мутацією - інсерцією EGFR у 20-му екзоні у поєднанні з позитивним PD-L-статусом.

Хворій Б. 1969 р.н. у березні 2018 р. було встановлено наступний клінічний діагноз: недрібноклітинний неплоскоклітинний рак нижньої частки правої легені рТ2а pN0 M0 G2 IB ст. Пацієнтка отримала 2 курси індукційної поліхіміотерапї (карбоплатин +паклітаксел), була проведена операція - радикальна нижня лобектомія справа. Результати патогістологічного дослідження імуногістохімії: помірнодиференційована папілярна аденокарцинома. У травні 2019 р. були виявлені метастази у надключичні лімфовузли справа. Результати патогістологічного дослідження імуногістохімії: помірнодиференційована аденокарцинома із заміщенням до 95\%. Було проведено молекулярне дослідження метастатичних зразків, яке показало наявність інсерції в 20-му екзоні гену $E G F R$, не було виявлено мутацій генів $A L K, R O S 1$, визначена слабопозитивна експресія PD-L1 (1\%). 


\section{Актуально / Topical}

Спочатку пацієнтка отримала 6 курсів поліхіміотерапії (карбоплатин+пеметрексед), а потім дистанційну гамматерапію (сумарна вогнищева доза 40 Гр на середостіння та 40 Гр на праву надключичну ділянку). Потім було зафіксоване прогресування хвороби - метастази в легені $($ рисунок, $a$ ). Після чого було призначено таргетну терапію ITK EGFR 3-го покоління - осимертиніб (80 мг), завдяки чому вдалося досягнути стабілізації захворювання через 3 міс терапії (частковий регрес пухлини $-8 \%$ по шкалі RECIST 1.1) (рисунок, б). Під час застосування осимертинібу відмічалися наступні побічні явища:

- слабкість 1 ступеня, яка була наявна протягом усього лікування;

- діарея 1 ступеня - у період з 3-го тижня, періодично;

- серйозні небажані ефекти не були зареєстровані.

Під час підготовки публікації Олександр Анатолійович поділився з редакцією журналу «Клінічна онкологія» оновленими результатами ведення згаданої пацієнтки. 3 грудня
2021 р. пацієнтка перейшла на дозування осимертинібу 160 мг. На комп’ютерній томографії від 09.03.2021 p. новоутворення у правій легені зменшилося 312 до 6,5 мм (рисунок, в). Новоутворення 5 мм в лівій легені зникло (рисунок, г). Надключичні лімфовузли, у яких під час біопсії було підтверджено прогресію захворювання, - не візуалізувалися. Пацієнтка захворіла на COVID-19 4 березня 2021 р. На комп'ютерній томографії від 09.03.2021 р. було виявлено $30 \%$ ураження легень. У березні пацієнтка захворіла на COVID-19, була госпіталізована у спеціалізоване відділення, отримувала меропенем. Наразі пацієнтка вилікувалася від COVID-19 і далі продовжує приймати осимертиніб у дозі 160 мг 1 раз на добу. Протягом лікування від COVID-19 прийом осимертинібу не припинявся!

Таким чином, можна резюмувати, що хоча проблема ефективної терапії пацієнтів з НДРЛ з рідкісними мутаціями EGFR залишається досить складною, наразі ми наблизилися до іï вирішення. Зокрема, дуже обнадійливими вигляда- 